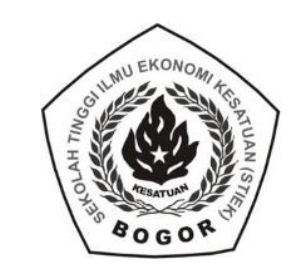

PROPOSAL KEGIATAN PPM DOSEN

\title{
PELATIHAN DIGITAL LIBRARY BAGI PENGELOLA PERPUSTAKAAN PERGURUAN TINGGI SE-BOGOR
}

\author{
Pelaksana: \\ Iswandi Sukartaatmadja \\ Husnul Toyibah \\ Mumuh Mulyana \\ Ade Yusdira
}

Kegiatan Pengabdian kepada Masyarakat ini dibiayai dengan dana LPM STIE Kesatuan Tahun 2019

\section{SEKOLAH TINGGI ILMU EKONOMI KESATUAN B O G O R 2019}




\section{HALAMAN PENGESAHAN}

1. Judul Penelitian

: Pelatihan Digital Library Bagi Pengelola Perpustakaan Perguruan Tinggi se Bogor

2. Bidang Penelitian

: Ekonomi

3. Ketua Tim Pelaksana
a. Nama Lengkap
: Iswandi Sukartaatmadja, SE., MM.
b. Jenis Kelamin
: Laki-laki
c. N I D N
$-\cdot-$
d. Disiplin Ilmu
e. Pangkat
: Ekonomi
f. Jabatan
g. Fakultas/Jurusan
h. Alamat
Lektor
: Dosen Tetap Program Studi Manajemen
i. Telpon/Faks/E-Mail
: Ekonomi / Manajemen
: Jl. Ranggagading No. 1 Bogor 16123
: 0251-8337733 / 0251-8319925 /

4. Jumlah Anggota Pelaksana : 3 Orang
a. Nama Anggota I
: Husnul Toyibah, SSos.
b. Nama Anggota II
c. Nama Anggota III
: Mumuh Mulyana, SE., MM., Msi
: Ade Yusdira, SE.

5. Lokasi Pengabdian

: Kota Bogor

6. Jumlah Biaya yang diusulkan : : Rp 6.000.000,-

(Enam juta rupiah)

Ketua STIE Kesatuan

Bogor, 22 Maret 2019

Yang Mengajukan,

Ketua Tim Pelaksana,

Dr. H. Bambang Pamungkas, Ak., MBA.

Iswandi Sukartaatmadja, SE., MM.

Mengetahui,

Ketua Lembaga Pengabdian Kepada Masyarakat

\section{Drs. H. Bambang Rahardjo, MM.}




\section{A. PENDAHULUAN}

\section{Analisis Situasi}

Perpustakaan Perguruan Tinggi merupakan salah satu sumber belajar yang mampu menyediakan buku untuk penunjang materi pembelajaran sesuai dengan kurikulum yang berlaku, sehingga memungkinkan bagi pengajar dan mahasiswa memanfaatkannya sebagai sumber informasi, sarana sekaligus sebagai media penunjang.

Dalam proses belajar mengajar dewasa ini, khususnya di Perguruan Tinggi dasar, pada kenyataannya sebagian besar belum memanfaatkan perpustakaan sebagai sumber belajar secara optimal. Hal ini disebabkan karena perpustakaan yang ada belum dikelola secara baik. Buku yang akan dipinjam cenderung sulit untuk diidentifikasi saat dibutuhkan. Kualitas pelayanan pun belum menjadi bagian utama dalam operasionalisasi perpustakaan. Akibatnya para mahasiswa pun enggan untuk memanfaatkan buku yang ada di perpustakaan. Melihat kondisi tersebut, maka Tim Pengabdian memandang perlu diselenggarakan sebuah program memberikan bantuan dalam bentuk pelatihan tentang pengelolaan perpustakaan Perguruan Tinggi.

\section{Perumusan Masalah}

Berdasarkan uraian di atas, ada beberapa identifikasi permasalahan di lapangan yang ditemui sebagai berikut :

a. perlu ada usaha untuk meningkatkan kualitas sumberdaya manusia khususnya para Pengelola Perpustakaan Perguruan Tinggi

b. masih rendahnya minat baca para mahasiswa

c. sebagian besar pengelola perpustakaan belum memahami teknis pengelolaan perpustakaan Perguruan Tinggi

d. terbatasnya sumberdaya perpustakaan perguruan tinggi sebagai sumber belajar

Berdasarkan identifikasi permasalahan di atas, dapat dirumuskan permasalahan untuk dibantu pemecahannya melalui pengabdian masyarakat ini sebagai berikut :

a. bagaimana menumbuhkan minat baca pada diri mahasiswa ?

b. bagaimana cara menanamkan pemahaman Pengelola Perpustakaan tentang teknis pengelolaan perpustakaan?

c. bagaimanakah cara penggalian sumberdaya untuk mengoptimalkan pemanfaatan perpustakaan?

\section{Tujuan Kegiatan PPM}

Kegiatan pengabdian kepada masyarakat ini bertujuan memberikan peningkatan kemanfaatan perpustakaan Perguruan Tinggi sebagai sumber belajar baik oleh pengajar maupun mahasiswa. Adapun tujuan khusus dari kegiatan pengabdian masyarakat ini adalah :

a. meningkatkan pengetahuan dan konsep tentang pengelolaan perpustakaan bagi para Pengelola Perpustakaan Perguruan Tinggi.

a. menanamkan keterampilan pada para Pengelola Perpustakaan dalam mengelola dan memanfaatkan perpustakaan sebagai sumber belajar. 


\section{Manfaat PPM}

Manfaat yang diharapkan dari pengabdian masyarakat ini adalah:

a. meningkatnya pemanfaatan perpustakaan Perguruan Tinggi sebagai sumber belajar baik oleh pengajar maupun mahasiswa

b. meningkatkan kerja sama akademik antara STIE Kesatuan dengan Perguruan Tinggi lainnya di Kota dan Kabupaten Bogor

c. membantu Pemerintah dan Direktorat Jendral Pendidikan Tinggi dalam melakukan pembinaan terhadap Perguruan Tinggi dalam mengelola perpustakaan Perguruan Tinggi.

\section{Tinjauan Pustaka}

Belajar mengajar sebagai suatu proses merupakan suatu sistem yang tidak terlepas dari komponen yang saling berinteraksi di dalamnya. Salah satu komponen dalam proses tersebut adalah sumber belajar. Sumber belajar adalah segala sesuatu yang dapat digunakan peserta didik untuk belajar, baik yang secara khusus dirancang oleh pengajar maupun secara alamiah tersedia di lingkungannya. Sumber belajar tersebut meliputi orang, alat, bahan, kegiatan/teknik, dan lingkungan. Dalam hal ini perpustakaan merupakan sumber belajar yang berbentuk lingkungan.

Dalam UU nomor 20 tahun 2003 tentang Sistem Pendidikan Nasional, menyebutkan bahwa perpustakaan merupakan salah satu sumber belajar yang sangat penting, yang memungkinkan para tenaga kependidikan dan peserta didik memperoleh kesempatan untuk memperluas dan memperdalam pengetahuan dengan membaca bahan pustaka yang mengandung ilmu pengetahuan yang diperlukan.

Di antara para ahli pendidikan ada yang berpendapat bahwa perpustakaan merupakan bagian integral dalam lembaga pendidikan. Sebagai bagian integral pada lembaga pendidikan, perpustakaan Perguruan Tinggi adalah unit kerja yang merupakan tempat menyimpan koleksi bahan pustaka yang dikelola dan diatur secara sistematis dengan cara tertentu untuk digunakan oleh mahasiswa dan pengajar sebagai sumber informasi dalam rangka menunjang proses belajar mengajar (Mulyani A Nurhadi,1983). Sedemikian pentingnya peranan perpustakaan tersebut sehingga sering diibaratkan sebagai jantung pendidikan yang memiliki kekuatan dan kemampuan yang langsung mempengaruhi mutu pendidikan.

Ironisnya banyak Perguruan Tinggi yang belum memanfaatkan perpustakaan Perguruan Tinggi sebagai sumber belajar. Buku/bahan pustaka yang ada di perpustakaan hanya dijadikan pajangan atau hiasan, dan tidak dikelola dan diatur dengan baik. Hal ini dikarenakan kurangnya Pengelola Perpustakaan dalam memahami pengelolaan perpustakaan yang baik yang memungkinkan mahasiswa menjadi aktif untuk memanfaatkan bahan pustaka di perpustakaan Perguruan Tinggi.

\section{B. PELAKSANAAN}

\section{Waktu Pelaksanaan}

Kegiatan pengabdian kepada masyarakat ini akan dilaksanakan pada hari Sabtu, 6 April 2019 pukul 08.00 s/d 14.00 WIB. Kegiatan ini diawali dengan langkah awal yaitu kegiatan observasi perpustakaan di Perguruan Tinggi di Kota dan Kabupaten Bogor. Selanjutnya menetapkan wakil Pengelola Perpustakaan Perguruan Tinggi dari 
setiap Perguruan Tinggi se Kota dan Kabupaten Bogor untuk mengikuti pelatihan pengelolaan perpustakaan Perguruan Tinggi dimaksud untuk kemudian dilanjutkan dengan proses komunikasi dan monitoring dari implikasi pasca pelatihan.

\section{Materi}

Materi yang dibahas dalam kegiatan pengabdian kepada masyarakat ini meliputi:

a. Manajemen dan Administrasi Perpustakaan

b. Instalasi software SLiMS

c. Modifikasi Tampilan

\section{Metode}

Untuk mencapai tujuan kegiatan pengabdian kepada masyarakat ini dengan menggunakan metode sebagai berikut.

a. Metode Ceramah/Penyuluhan, dimaksudkan untuk menyampaikan informasi untuk materi yang bersifat umum dan teoritis, dalam hal ini adalah materi pengelolaan perpustakaan Perguruan Tinggi.

b. Metode Dialogis, dimaksudkan untuk tanya jawab dan diskusi tentang bagaimana mengelola perpustakaan Perguruan Tinggi.

c. Metode Pelatihan, dimaksudkan untuk menanamkan kecakapan dan ketrampilan teknis dan praktis dalam pengelolaan perpustakaan Perguruan Tinggi, dan memberikan gambaran konkrit di lapangan tentang pengelolaan perpustakaan Perguruan Tinggi.

\section{DAFTAR PUSTAKA}

Muljani A Nurhadi, 1983, Perpustakaan Perguruan Tinggi, Willis, Yogyakarta.

UU Nomor 20 Tahun 2003, tentang Sistem Pendidikan Nasional

Nurendah, Y., Mulyana, M. and Muanas, M., 2018. Evaluasi dan Pemetaan Minat Studi Siswa SMA dan SMK di Kota Bogor Pada Program Studi Ekonomi Syariah. JAS-PT Jurnal Analisis Sistem Pendidikan Tinggi, 2(2), pp.83-94.

Sulistiono, S., Nurendah, Y. and Mulyana, M., 2019. Mengukur Minat Studi Siswa SMA dan SMK di Kota Bogor Pada Program Studi Kewirausahaan. JAS-PT Jurnal Analisis Sistem Pendidikan Tinggi, 3(1), pp.1-12.

Mekaniwati, A. and Setiana, A., 2018. Analisis Minat Pada STIE Kesatuan Bogor Dengan Pendekatan Motivasi, Kepribadian Dan Karakteristik Wirausahawan. Jurnal Ilmiah Manajemen Kesatuan, 6(2), pp.130-137.

Hasibuan, D.HM., Nuraini, A. and Wahyuningsih, D., 2017. Sosialisasi Penyusunan Laporan Keuangan Dan Perencanaan Pajak Entitas Nirlaba Untuk Yayasan. Jurnal Abdimas, 1(1), pp.16-19.

Andi Yudha AP, A.Y., Marlina, T. and Fahmi, A., 2017. Pelatihan Membuat Laporan Keuangan Dengan Microsoft Excel Bumdes Pagelaran. Jurnal Pengabdian Masyarakat, 1(1).

Mekaniwati, A. and Setiana, A., 2018. Interest Analysis on Sekolah Tinggi Ilmu Ekonomi Kesatuan Bogor Students With Motivation Approach, Personality and Entrepreneurial Characteristics. In THE INTERNATIONAL CONFERENCE ON ACCOUNTING AND MANAGEMENT SCIENCE (p. 309). 



\section{Perkiraan Biaya Pelaksanaan Pengabdian}

Rencana Pemasukan:

A. Dana Pendaftaran Peserta 10 x @ Rp 300.000,-

B. Alokasi Dana Pengabdian Masyarakat

Rp 3.000 .000

Rp $\quad 825.000$

Jumlah

Rp 3.325.000

Rencana Pembiayaan:

A. Biaya Bahan dan Alat

1. Block Note $15 \mathrm{x} @ \mathrm{Rp} 10.000,-$

Rp. $\quad 150.000$

2. Alat-alat tulis $15 \mathrm{x} @ \mathrm{Rp} 10.000$,-

Rp. $\quad 150.000$

3. CD 15 buah @5000

Rp. $\quad 75.000$

4. Paper Bag 15 x @ Rp 15.000,-

Rp. $\quad 225.000$

5. Nametag $15 \mathrm{x} @$ Rp 5.000,-

Rp. $\quad 75.000$

6. Makalah15x@Rp10.000

Rp. $\quad 150.000$

Jumlah

Rp. $\quad 825.000$

B. Biaya Operasional

1. Honor Pembicara 3 orang @500.000

Jumlah

Rp. 1.500 .000

Rp. $\quad 1.500 .000$

C. Biaya Transportasi dan Akomodasi

1. Coffee Break $20 \mathrm{x} @ \mathrm{Rp} 15.000,-$

Rp. $\quad 300.000$

2. Makan Siang 20 x @ Rp 25.000,-

Rp $\quad 500.000$

3. Distribusi Surat Menyurat

Rp $\quad 500.000$

Jumlah

Rp. $\quad 1.300 .000$

D. Biaya Lain-lain

1. Biaya tak terduga

Jumlah

Rp. $\quad 200.000$

Rp. $\quad 200.000$

Jumlah A+B+C+D

Rp. 3.825 .000 